\title{
COMPOSITION OF METAMICT ZIRCON FROM MOZAMBIQUE
}

\author{
RAGNAR TÖRNROOS
}

TÖNROOS RAGNAR 1982: Composition of metamict zircon from Mozambique. Bull. Geol. Soc. Finland 54, 1-2, 77-83.

Nine specimens of metamict zircon from granite pegmatites of the district of Zambézia, Mozambique, have been analyzed by wet chemical methods and by X-ray fluorescence.

The specimens, which are contaminated by xenotime, display low densities and a low degree of order with only a few of the strongest zircon lines in the X-ray powder pattern. The mineral apparently crystallized in open wugs. The high water content is considered interstitial incorporated in the structure, not as $\square(\mathrm{OH})_{4}^{-}$ replacing $\mathrm{SiO}_{4}$. The incorporation of water into the structure may have been simultaneous with the crystallization and metamictization of the mineral.

Ragnar Törnroos. Geological Survey of Finland, SF-02150 Espoo 15, Finland.

\section{Introduction}

The bedrock of the district of Zambézia in northern Mozambique contains a number of granite pegmatites well known for their wide variety of rare minerals. A brief account of the pegmatite localities has been given by Correia Neves et al. (1971).

Beautiful specimens of zircon have been collected from some of the localities. These zircons are in a highly metamict state and offer a good opportunity to study the metamictization process. Since no complete chemical analyses of these metamict Zambézia zircons are reported in the literature, it seems pertinent to present here some data on them.

Some authors refer to a metamict zircon as malacon. Because malacon is not the name of a species, however, but applies to a meta- mict variety of the mineral zircon, it will not be used in this paper.

\section{Materials}

The material for this study consists of nine metamict zircon specimens from the Zambézia granite pegmatites. Six of the specimens were obtained from the collections of the Geology Department of the University of Maputo (formerly Lourenço Marques) and are labeled L. M. (courtesy: professors J. M. Correia Neves and J. E. Lopes Nunes). The remaining three specimens were collected in the field by professor Th.G. Sahama, who placed all the specimens at the author's disposal.

The numbering of the specimens used throughout this paper, together with the localities from which they originate, is given 


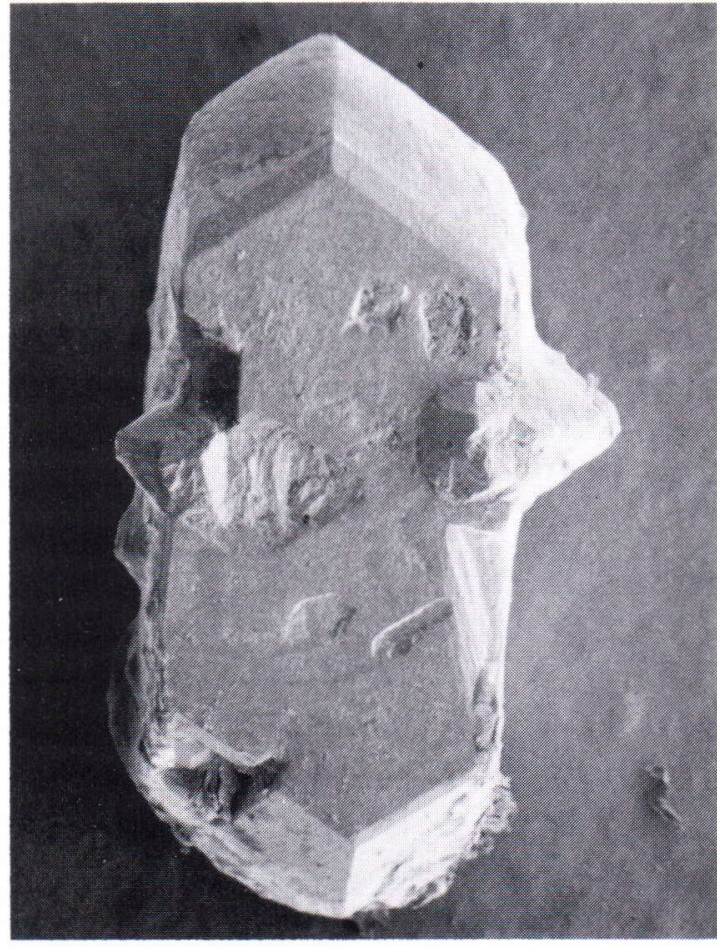

Fig. 1. Bipyramidal xenotime in parallel growth with prismatic zircon. Specimen L. M. 4627. Boa Esperança, Ribaué. Scanning electron micrograph. Crystal length $1 \mathrm{~mm}$.

in the legend of Table 1. Specimen No. 1 is a 'zircon concentrate with euhedral, prismatic crystals up to $1 \mathrm{~mm}$ long. The remaining specimens Nos. 2-9 consist of groups of euhedral to subhedral crystals, partly in a subparallel arrangement. The appearance of the specimens suggests strongly that the zircon crystals were grown from the smooth walls of open wugs. The crystal faces are brown in colour. When broken, the crystals appear heterogeneous with irregular yellow, green, brown and even black domains, all with a greasy lustre. The broken pieces are mostly translucent and only rarely transparent.

The dominant crystal form is a combination of $\{110\}$ and $\{101\}$, commonly with slightly curved faces. The forms were check- ed with X-ray precession photographs of a crystal from specimen No. 1. Some crystals also show narrow forms of $\{100\},\{211\}$ and $\{321\}$.

The following minerals are associated with the metamict zircon: xenotime, quartz, columbite-tantalite, microlite, garnet, thorite, albite (cleavelandite), mica, anatase, bismutite, beryl and goethite. A parallel growth of zircon and xenotime is illustrated in Fig. 1.

\section{Sample treatment}

The metamict zircon contained numerous cracks with brownish material in the seams. The mineral was crushed, and pure pieces of various colours were picked by hand under a binocular microscope. To remove the bulk of the extraneous crack-filling material, each hand-picked sample was treated with an ultrasonic cleaner in alcohol and eluted in water. Any magnetic contaminations were removed with a Frantz isodynamic separator, and the light mineral inclusions (density $<3.9$ ) were separated by centrifuging in Clerici solution.

The density was then determined with a Notari volumeter by measuring the volume of the sample and comparing it with a standard of approximately the same volume and the same grain size. Hedenbergite with a density of 3.482 was used as the standard. For a couple of samples the results, considered accurate to \pm 0.04 , were checked by measurements with a Berman balance.

Next the material was ground in acetone to a grain size of c. $3 \mu \mathrm{m}$. The fine-grained samples were used for the analysis.

The analyses were performed as follows: $\mathrm{SiO}_{2}, \mathrm{Fe}_{2} \mathrm{O}_{3}, \mathrm{CaO}$ and water were determined by routine wet chemical methods. Two precipitates were prepared: one containing $\mathrm{ZrO}_{2}+\mathrm{HfO}_{2}+\mathrm{P}_{2} \mathrm{O}_{5}$ and one $\mathrm{U}$, Th and the rare earth elements as oxides. This part of the work was done by Dr. O. v. Knorring. 
Table 1. Chemical composition of metamict zircon from Zambézia, Mozambique. New analyses.

\begin{tabular}{|c|c|c|c|c|c|c|c|c|c|}
\hline $\begin{array}{l}\text { Weight } \\
\text { percent }\end{array}$ & 1 & 2 & 3 & 4 & 5 & 6 & 7 & 8 & 9 \\
\hline $\mathrm{SiO}_{2}$ & 30.38 & 27.86 & 26.30 & 27.80 & 27.13 & 26.82 & 27.46 & 27.39 & 26.69 \\
\hline $\mathrm{ZrO}_{2}$ & 60.23 & 56.62 & 51.11 & 55.42 & 51.76 & 54.81 & 51.68 & 49.30 & 45.40 \\
\hline $\mathrm{HfO}_{2}$ & 3.89 & 4.30 & 4.82 & 4.85 & 7.40 & 8.55 & 11.56 & 12.18 & 21.24 \\
\hline $\mathrm{Fe}_{2} \mathrm{O}_{3}$ & 1.00 & 1.19 & 0.44 & 1.48 & 0.89 & 1.86 & 1.11 & 0.97 & 0.56 \\
\hline $\mathrm{CaO}$ & 0.44 & 1.18 & 0.51 & 0.42 & 0.52 & 0.89 & 1.20 & 0.55 & 0.98 \\
\hline $\mathrm{P}_{2} \mathrm{O}_{5}$ & 0.56 & 1.00 & 3.86 & 1.93 & 2.41 & 0.99 & 0.50 & 1.62 & 0.56 \\
\hline $\mathrm{Y}_{2} \mathrm{O}_{3}$ & 0.41 & 1.25 & 3.54 & 2.28 & 2.53 & 0.79 & 0.20 & 1.92 & 0.17 \\
\hline$(\mathrm{La}-\mathrm{Lu})_{2} \mathrm{O}_{3}$ & 1.10 & 1.95 & 4.26 & 1.54 & 2.13 & 1.45 & 0.84 & 1.42 & 0.46 \\
\hline $\mathrm{ThO}_{2}$ & 0.04 & 0.22 & 0.17 & 0.24 & 0.11 & 0.08 & 0.12 & 0.14 & 0.16 \\
\hline $\mathrm{UO}_{2}$ & nil & 0.03 & nil & nil & 0.02 & nil & 0.02 & 0.01 & 0.04 \\
\hline $\mathrm{H}_{2} \mathrm{O}+$ & 1.69 & 4.07 & 4.33 & 3.45 & 4.28 & 3.25 & 4.42 & 3.73 & 3.61 \\
\hline $\mathrm{H}_{2} \mathrm{O}-$ & 0.45 & 0.60 & 0.81 & 0.65 & 0.61 & 0.58 & 0.91 & 0.73 & 0.47 \\
\hline Total & 100.19 & 100.27 & 100.15 & 100.06 & 99.79 & 100.07 & 100.02 & 99.96 & 100.34 \\
\hline \multicolumn{10}{|c|}{ Cation percent } \\
\hline $\mathrm{Si}$ & 48.12 & 45.65 & 43.84 & 45.46 & 45.36 & 44.66 & 46.60 & 46.20 & 46.72 \\
\hline $\mathrm{Zr}+\mathrm{Hf}$ & 48.28 & 47.25 & 43.84 & 46.45 & 45.77 & 48.56 & 48.37 & 46.42 & 49.37 \\
\hline $\mathrm{Fe}$ & 1.19 & 1.47 & 0.55 & 1.82 & 1.12 & 2.33 & 1.42 & 1.23 & 0.74 \\
\hline $\mathrm{Ca}$ & 0.74 & 2.07 & 0.91 & 0.74 & 0.93 & 1.59 & 2.18 & 0.99 & 1.84 \\
\hline $\mathrm{P}$ & 0.75 & 1.39 & 5.45 & 2.67 & 3.42 & 1.39 & 0.71 & 2.31 & 0.83 \\
\hline $\mathrm{Y}+(\mathrm{La} . . \mathrm{Lu})$ & ) 0.90 & 2.09 & 5.35 & 2.78 & 3.36 & 1.44 & 0.65 & 2.80 & 0.42 \\
\hline Th & 0.02 & 0.08 & 0.06 & 0.09 & 0.04 & 0.03 & 0.05 & 0.05 & 0.06 \\
\hline $\mathrm{U}$ & nil & 0.01 & nil & nil & 0.01 & nil & 0.01 & $<0.01$ & 0.02 \\
\hline$\frac{100 \cdot \mathrm{Hf}}{\mathrm{Zr}+\mathrm{Hf}}$ & 3.6 & 4.3 & 5.2 & 4.9 & 7.7 & 8.4 & 11.6 & 12.6 & 21.5 \\
\hline \multicolumn{10}{|c|}{ Atomic proportions of the rare earth elements based on $\mathrm{La}+\ldots \mathrm{Lu}=100$} \\
\hline $\mathrm{La}$ & 2.5 & nil & 0.7 & 1.6 & 0.8 & nil & 1.1 & 1.5 & 1.5 \\
\hline $\mathrm{Ce}$ & 15.3 & nil & 0.3 & 5.1 & 2.2 & 4.8 & 17.5 & 4.5 & 6.2 \\
\hline $\operatorname{Pr}$ & 1.1 & 0.3 & nil & 0.6 & nil & nil & 2.1 & nil & 1.2 \\
\hline $\mathrm{IJd}$ & 3.0 & 1.3 & nil & 1.6 & 0.7 & 0.4 & 6.8 & 2.0 & 2.2 \\
\hline $\mathrm{Sm}$ & 2.4 & 1.2 & 0.6 & 1.3 & 0.7 & 1.5 & 7.3 & 2.3 & 2.3 \\
\hline $\mathrm{Eu}$ & 0.2 & 0.4 & 0.3 & 0.3 & nil & 0.2 & 0.4 & nil & 1.4 \\
\hline $\mathrm{Gd}$ & 3.6 & 1.4 & 1.5 & 4.1 & 2.1 & 1.6 & 9.3 & 10.3 & 22.3 \\
\hline Dy & 12.1 & 9.1 & 10.4 & 23.7 & 13.0 & 5.6 & 19.0 & 31.8 & 30.7 \\
\hline Ho & 4.9 & 3.2 & 4.7 & 7.7 & 5.2 & 2.2 & 7.5 & 11.0 & 16.4 \\
\hline Er & 12.7 & 12.2 & 17.2 & 16.2 & 18.1 & 8.0 & 6.2 & 10.6 & 3.7 \\
\hline $\mathrm{Tm}$ & 1.9 & 2.7 & 2.8 & 1.2 & 2.7 & 2.3 & 1.9 & nil & 1.0 \\
\hline $\mathrm{Yb}$ & 31.7 & 51.3 & 49.3 & 29.2 & 44.6 & 53.5 & 14.9 & 18.2 & 5.1 \\
\hline $\mathrm{Lu}$ & 8.5 & 16.9 & 12.2 & 7.5 & 9.9 & 20.0 & 6.0 & 7.8 & 5.9 \\
\hline $\mathrm{Y}$ & 61 & 110 & 143 & 249 & 203 & 94 & 39 & 224 & 60 \\
\hline
\end{tabular}

List of pegmatite localities of the specimens.

No. 1. Boa Esperança, Ribaué. Specimen L.M. 4627.

No. 2. Guilherme I, Nauela. Specimen L.M. 4368.

No. 3. Meco, Nauela. Specimen L.M. 3180.

No. 4. Boa Esperança, Ribaué. Specimen L.M. 5189.

No. 5. Nachaca, Nauela. Specimen L.M. 4399.

No. 6. Muiane. Specimen 4.

No. 7. Nuaparra. No specimen number.

No. 8. Boa Esperança, Ribaué. Specimen L.M. 4423.

No. 9. Muiane. Specimen 3. 
Using known mixtures of oxides as standards (for $\mathrm{P}_{2} \mathrm{O}_{5}$ a phosphate rock, National Bureau of Standards reference material 120b), Mrs. Tuula Holtari analyzed the two precipitates by X-ray fluorescence.

\section{Chemistry}

The chemical compositions of the metamict zircon samples analyzed are reproduced in Table 1.

The X-ray powder patterns (Philips wideangle goniometer, filtered copper radiation) of the unheated materials for analysis revealed xenotime as a contamination, the presence of which was confirmed by thin-section microscopy. The approximate amount of xenotime in the samples was estimated by comparing the peak heights of the (200) lines of xenotime and zircon. The samples were heated for 4 to 5 hours at $1000^{\circ} \mathrm{C}$ and the averages of ten diffractometer runs were adopted. The intensity ratio between the xenotime and zircon lines was calibrated with known mixtures of xenotime and fully ordered zircon. It was found that the xenotime content of the samples thus obtained agreed roughly with the amount of xenotime calculated from the figure for $\mathrm{P}_{2} \mathrm{O}_{5}$ in the analysis report. A plot of the sum of the rare earth elements against phosphorus in cation percent (Fig. 2) reveals that, allowing for analytical uncertainties, the ratio $\mathrm{RE}: \mathrm{P}$ approximates $1: 1$. It is concluded that virtually all the $(\mathrm{RE})_{2} \mathrm{O}_{3}$ and $\mathrm{P}_{2} \mathrm{O}_{5}$ shown by the analyses are included in the admixed xenotime phase. The relative amounts of lanthanides shown in Table 1. indicate a predominance of yttrium and of the heavy lanthanides in accordance with the known composition of the mineral xenotime.

Fig. 3 plots $\mathrm{Si}$ against the sum of $(\mathrm{Zr}+\mathrm{Hf})$ in cation percent. This figure demonstrates that many of the zircons studied display a marked deficiency in silicon compared with

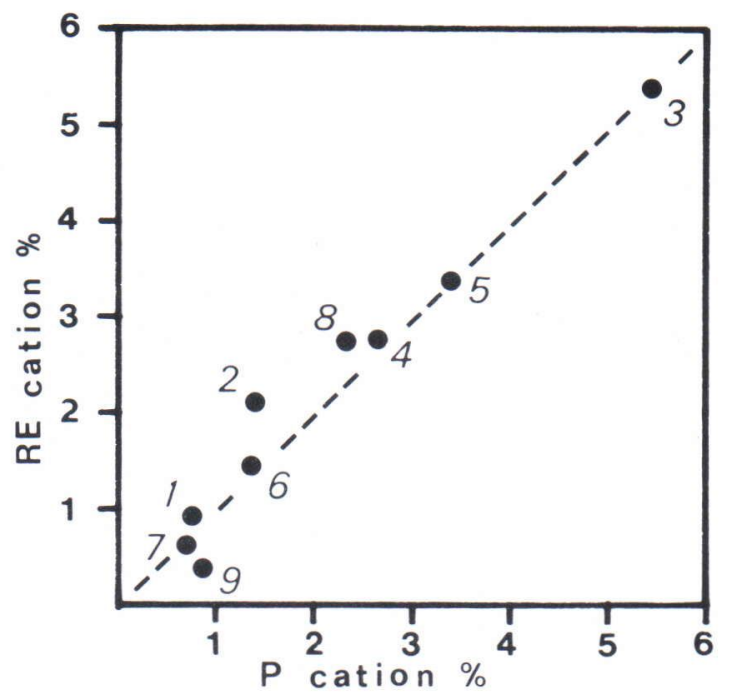

Fig. 2. Rare earths plotted against phosphorus. Cation percent. Broken line indicates $\mathrm{RE}: \mathrm{P}=1: 1$. Numbering refers to Table 1.

the theoretical formula $(\mathrm{Zr}, \mathrm{Hf}) \mathrm{SiO}_{4}$. The deficiency exceeds any possible analytical errors. What is more, the content of $\mathrm{H}_{2} \mathrm{O}+$ is high in all the samples; higher than is needed for compensating the deficiency in $\mathrm{SiO}_{2}$. It is concluded that, although some water may replace the silicon tetrahedra as tetrahedral groups $\square(\mathrm{OH})_{4}$, most of the $\mathrm{H}_{2} \mathrm{O}+$ must be interstitially in the structure.

As was mentioned earlier, the mineral thorite was identified in the original specimens. The contents of $\mathrm{ThO}_{2}$ in the samples analyzed (Table 1) are too low to produce detectable lines in the X-ray diffractograms. It is not possible to tell whether thorium is present as an independent thorite phase or whether it is incorporated in the structure or zircon or xenotime. The uranium content is conspicuously low. The amounts of Th and $\mathrm{U}$ that may have been present in the crack fillings were mostly, if not entirely, removed by grinding and ultrasonic cleaning during the preparation of the samples for analysis.

The $\mathrm{HfO}_{2}$ contents range up to fairly high values. Specimen No. 9 represents the most Hf-rich metamict zircon known so far. 


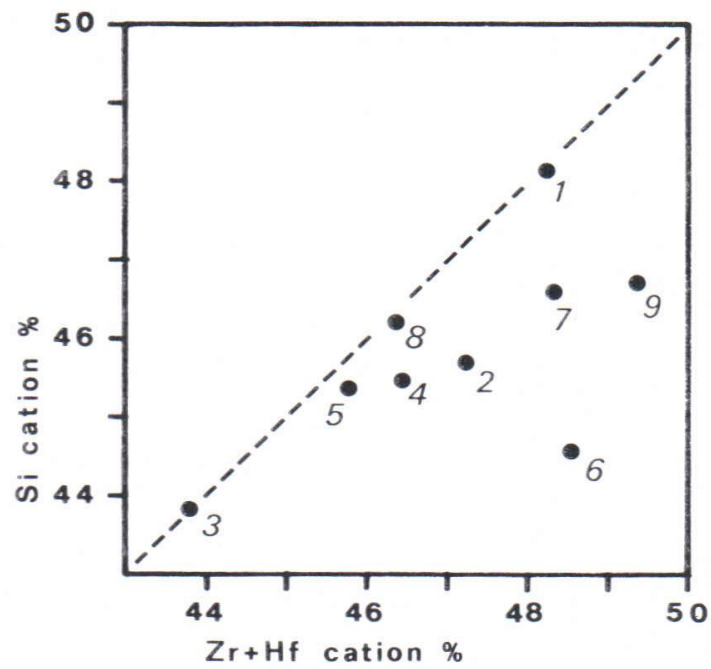

Fig. 3. Si plotted against $(\mathrm{Zr}+\mathrm{Hf})$. Cation percent. Broken line indicates $\mathrm{Si}:(\mathrm{ZrHf})=1: 1$. Numbering refers to Table 1 .

\section{Cell data and density}

The X-ray powder diffractograms prepared from the unheated samples Nos. 1-9 display only the strongest zircon lines. These lines are broad and diffuse. Within the accuracy attain- able in the measurement, the d-value of a particular line remains virtually constant in all the specimens. The following approximation of the cell data on these metamict zircons could thus be given: $\mathrm{a}=6.62 \AA, \mathrm{c}=6.06 \AA$ (both $\pm 0.02 \AA$ ), volume $=266 \AA^{3}$.

The powder lines become sharp after heating for 4 to 5 hours at $1000^{\circ} \mathrm{C}$. The cell data on the heated materials are compiled in Table 2. The data vary only slightly, averaging $\mathrm{a}=6.608 \AA$ (standard deviation $0.004 \AA$ ), $\mathrm{c}=6.000 \AA$ (st. dev. $0.005 \AA$ ) and volume $=262.0 \AA^{3}$ (st. dev. $0.2 \AA^{3}$ ).

Table 2. also lists the measured densities and unit cell contents of the unheated materials. The values are compared with those calculated on the basis of the unit cell $\mathrm{Si}+$ $\mathrm{Zr}+\mathrm{Hf}+\mathrm{Fe}+\mathrm{Ca}+\mathrm{H}_{2} \mathrm{O}(+)=8.00$ and volume $=266 \AA^{3}$. This way of calculating the densities is admittedly crude; the chemical composition of a metamict zircon cannot be expected to be stoichiometric, the distinction between $\mathrm{H}_{2} \mathrm{O}+$ and $\mathrm{H}_{2} \mathrm{O}$ - is necessarily more or less arbitrary, and the value for the unit cell volume is only an approximation. A compari-

Table 2. Cell data and density of metamict zircon from Mozambique. Numbering refers to Table 1.

$\begin{array}{llllllllll}1 & 2 & 3 & 4 & 5 & 6 & 7 & 8 & 9\end{array}$

Unit cell dimensions: samples heated for $4-5$ hours at $1000^{\circ} \mathrm{C}$, uncertainty $\pm 0.003 \AA$

\begin{tabular}{|c|c|c|c|c|c|c|c|c|c|}
\hline $\begin{array}{l}\mathrm{a}(\AA) \\
\mathrm{c}(\AA) \\
\text { Volume }\left(\AA^{3}\right)\end{array}$ & $\begin{array}{r}6.606 \\
6.000 \\
261.8\end{array}$ & $\begin{array}{l}6.608 \\
6.008 \\
262.3\end{array}$ & $\begin{array}{c}6.612 \\
5.996 \\
262.1\end{array}$ & $\begin{array}{c}6.613 \\
5.992 \\
262.0\end{array}$ & $\begin{array}{c}6.611 \\
5.999 \\
262.2\end{array}$ & $\begin{array}{c}6.610 \\
5.992 \\
261.8\end{array}$ & $\begin{array}{c}6.605 \\
6.004 \\
261.9\end{array}$ & $\begin{array}{r}6.604 \\
6.004 \\
261.9\end{array}$ & $\begin{array}{r}6.603 \\
6.001 \\
261.6\end{array}$ \\
\hline \multicolumn{10}{|c|}{ Unit cell content: basis see text } \\
\hline $\begin{array}{l}\mathrm{Si} \\
\mathrm{Zr}+\mathrm{Hf} \\
\mathrm{Fe} \\
\mathrm{Ca} \\
\mathrm{H}_{2} \mathrm{O}+ \\
\mathrm{H}_{2} \mathrm{O}- \\
\mathrm{O}\end{array}$ & $\begin{array}{r}3.59 \\
3.60 \\
0.09 \\
0.06 \\
0.67 \\
0.18 \\
14.58\end{array}$ & $\begin{array}{r}3.08 \\
3.19 \\
0.10 \\
0.14 \\
1.50 \\
0.22 \\
12.83\end{array}$ & $\begin{array}{r}3.10 \\
3.10 \\
0.04 \\
0.06 \\
1.70 \\
0.32 \\
12.52\end{array}$ & $\begin{array}{r}3.21 \\
3.28 \\
0.13 \\
0.05 \\
1.33 \\
0.25 \\
13.23\end{array}$ & $\begin{array}{r}3.10 \\
3.13 \\
0.08 \\
0.06 \\
1.63 \\
0.23 \\
12.64\end{array}$ & $\begin{array}{r}3.10 \\
3.37 \\
0.16 \\
0.11 \\
1.25 \\
0.22 \\
13.29\end{array}$ & $\begin{array}{r}3.02 \\
3.13 \\
0.09 \\
0.14 \\
1.62 \\
0.33 \\
12.58\end{array}$ & $\begin{array}{r}3.19 \\
3.21 \\
0.08 \\
0.07 \\
1.45 \\
0.28 \\
12.99\end{array}$ & $\begin{array}{r}3.12 \\
3.30 \\
0.05 \\
0.12 \\
1.41 \\
0.18 \\
13.04\end{array}$ \\
\hline \multicolumn{10}{|l|}{ Density } \\
\hline $\begin{array}{l}\text { Measured } 1 \\
\text { Calculated }^{2}\end{array}$ & $\begin{array}{l}4.32 \\
4.35\end{array}$ & $\begin{array}{l}3.96 \\
3.98\end{array}$ & $\begin{array}{l}3.94 \\
3.90\end{array}$ & $\begin{array}{l}3.98 \\
4.07\end{array}$ & $\begin{array}{l}3.96 \\
3.97\end{array}$ & $\begin{array}{l}4.25 \\
4.19\end{array}$ & $\begin{array}{l}4.00 \\
4.05\end{array}$ & $\begin{array}{l}4.12 \\
4.15\end{array}$ & $\begin{array}{l}4.26 \\
4.34\end{array}$ \\
\hline
\end{tabular}

1 Corrected for the xenotime contamination, uncertainty \pm 0.04 .

2 Basis see text. 
son of the measured densities with the calculated ones, however, seems to indicate that water is an essential component in the structure of a metamict zircon.

\section{Discussion}

The subhedral to euhedral habit of the metamict zircon crystals from Mozambique suggests that the mineral originally crystallized with a higher degree of order but that this was subsequently lowered by metamictization. It is difficult to estimate the minimum degree of order still capable of producing an euhedral zircon crystal.

The metamict zircon specimens analyzed in this study were obtained from the museum or were given by people working in pegmatite quarries. The original mode of occurrence of the pegmatite body is, therefore, not known to the author. The shape of the specimens Nos. 2-9 makes it highly probable that the metamict zircon crystals grew on the walls of open wugs. Although this statement is not based on field observations, it seems reasonable to assume that the minerals crystallized in an environment rich in $\mathrm{H}_{2} \mathrm{O}, \mathrm{F}$, etc. According to Caruba et al. (1975), such an environment facilitates the replacement of $\mathrm{SiO}_{4}$ by $\square(\mathrm{OH})_{4}$ in the zircon structure. The crystallizing zircon will thus show the formula $\mathrm{Zr}\left(\mathrm{SiO}_{4}\right)_{1-\mathrm{x}}(\mathrm{OH})_{4 \mathrm{x}}$.

As is shown by the unit cell content data in Table 2, the water contents of the metamict zircons analyzed in this study are higher than is required by the above formula. The bulk of the $\mathrm{H}_{2} \mathrm{O}+$ cannot replace $\mathrm{SiO}_{4}$ in the form of $\square(\mathrm{OH})_{4}$ without causing a serious deficiency in $\mathrm{Zr}+\mathrm{Hf}$. It seems more probable that the water is present interstitially and nonstoichiometrically in the structure of the mineral. This conclusion is in accord with the variation of the composition in the natural zircon-thorite series (Mumpton and Roy, 1961).

It is well known that metamictization is caused or, at least, greatly facilitated by the effect of nuclear radiation from the decay of $\mathrm{U}$, Th and their daughter elements. Studies on the process have been reviewed by several authors, e.g., Caruba et al. (1975) and Sommerauer (1976), and will not be recapitulated here. Although the $U$ and Th contents of the Mozambique metamict zircons are low (Table 1.), the sample treatment has probably removed some portions of these elements. In addition, it is highly probable that the medium from which the zircon crystallized was sufficiently enriched in $U$ and $T h$ to compel the process of metamictization to its present stage. The incorporation of water into the structure of the growing zircon crystal could be simultaneous with the progress of the disordering process.

The tantalum pegmatites of Mozambique are known to contain zircons rich in hafnium (Quadrado and Lima de Faria, 1966; Correia Neves et al. 1974). The most Hf-rich members of the zircon-hafnon series known so far display a high degree of order. Whether a high Hf content will increase the resistivity of the structure against the effect of nuclear radiation remains to be studied.

Acknowledgments. The author is indebted to professors J. M. Correia Neves and J. E. Lopes Nunes, formerly of the University of Maputo, Mozambique, for the specimens from the departmental collection; to professor Th.G. Sahama, of the University of Helsinki, Finland, for placing the specimens at the author's disposal; to Dr. O.v. Knorring, formerly of Leeds University, U. K., for the chemical analyses; and to Mrs. Tuula Holtari, of Outokumpu Oy, Espoo, Finland, for the $\mathrm{X}$-ray fluorescence work. 


\section{References}

Caruba, R., Baumer, A., Mano, J., Turco, G., 1975. Etude comparative des propriétés respectives de zircons hydroxylés synthétiques et de zircons métamictes naturels; hypothèse de genèse des malacons. Petrologie, 1, 57-70.

Correia Neves, J. M., Lopes Nunes, J. E., Lucas, D. B., 1971. Mineralogy and structure of some pegmatites from Mozambique (P.E.A.) - A Review. Revista de Ciências Geologicas, 4, $35-72$.

Correia Neves, J. M., Lopes Nunes, J. E., Sahama, Th.G., 1974. High hafnium members of the zircon-hafnon series from the granite peg- matites of Zambézia, Mozambique. Contrib. Mineral. Petrol., 48, 73-80.

Mumpton, F. A., Roy, R., 1961. Hydrothermal stability studies of the zircon-thorite group. Geochim. Cosmochim. Acta, 21, 217-238.

Quadrado, R., Lima de Faria, J., 1966. High hafnium zircon from Namacotche, Alto Ligonha, Mozambique. Garcia de Orta, 14, 311-316. Sommerauer, J., 1976. Die chemisch-physikalische Stabilität natürlicher Zirkone und ihr U-(Th)$\mathrm{Pb}$ System. Dissertation Nr. 5755, Eidg. Techn. Hochschule, Zürich.

Manuscript received, May 5, 1982 